Article

\title{
Leishmanicidal Activity of Aliphatic and Aromatic Lactones: Correlation Structure-Activity
}

\author{
Marcela Castaño ${ }^{1}$, Wilson Cardona ${ }^{2}$, Winston Quiñones ${ }^{1}$, Sara Robledo ${ }^{3}$ and \\ Fernando Echeverri ${ }^{1, *}$
}

1 Grupo de Química Orgánica de Productos Naturales-SIU, Universidad de Antioquia, P.O. Box 1226, Medellín, Colombia

2 Instituto de Química, Universidad de Antioquia, Universidad de Antioquia, P.O. Box 1226, Medellín, Colombia

3 PECET-SIU, Universidad de Antioquia, P.O. Box 1226, Medellín, Colombia

* Author to whom correspondence should be addressed; E-mail: echeveri@udea.edu.co; Tel.: +57-4-2105658; Fax: +57-4-2330120

Received: 7 June 2009 / Accepted: 18 June 2009 / Published: 10 July 2009

\begin{abstract}
Several aliphatic and aromatic lactones and two dimers were synthesized using the sequence: allylation - esterification - metathesis. These compounds were active in vitro against intracellular amastigotes of Leishmania panamensis. The structure-activity relationship showed the importance of the aliphatic side chain to enhance the biological activity and to obtain lower cytotoxicity. It was also observed that a decrease in the size of the lactone ring increases the selectivity index.
\end{abstract}

Keywords: metathesis; lactones; antiparasite; leishmania

\section{Introduction}

Protozoan parasites are responsible for some of the most common and devastating diseases affecting humans and animals [1]. Among these diseases is leishmaniasis, which causes more deaths after malaria [2], the reason why it has become a priority for the World Health Organization (WHO) [2]. Classical antiparasite drugs are highly toxic and are largely no longer effective because of the emergence of resistance in the parasites, thus becoming a major public health problem [3]. Therefore, it is necessary to search for new active-low-toxicity molecules which may be obtained from the structural modification of natural compounds through organic synthesis. 
Lactone rings are a structural feature of many natural products [4-7]. Many naturally occurring lactones, particularly $\alpha, \beta$-unsaturated ones that are Michael acceptors, display interesting pharmacologic properties [4]. Recently, several lactones and analogues such as argentilactone [8], boronolide [9] and passifloricin A [10] have been synthesized and have exhibited high activity against Leishmania panamensis amastigotes.

The olefin metathesis reaction has become a powerful tool in organic synthesis. One of its most successful applications is the ring closing metathesis reaction (RCM) which affords cyclic compounds from diolefinic precursors [11-16]. Among the different kinds of cyclic compounds obtainable by RCM, unsaturated lactones of various ring sizes are achievable from $\alpha, \omega$-diolefinic esters using firstand/or second-generation Grubbs's catalysts. More specifically, the preparation of $\alpha, \beta$ unsaturated $\gamma$ lactones through RCM of allyl and homoallyl acrylate have been reported using second-generation (II) Grubbs' catalysts [17-20].

Aiming at exploring the structure-activity relationships of the products, we previously reported some structural analogues of the mentioned compounds above [10]. However, in spite of the significant leishmanicidal activity against $L$. panamensis of some of these synthetic analogues, high cytotoxicity [21] was also observed, as well as the fact that the activity does not depend on the stereochemistry of the lactone ring [10]. Based on these results other racemic lactones analogues were synthesized by introducing aromatic rings in the chain and changing the type of lactone ring. In this paper we describe the synthesis these new analogues and their activity against Leishmania panamensis.

\section{Results and Discussion}

\subsection{Synthetic plan}

The synthesis of lactones was carried out following the methodology described in the literature [10]: allylation, esterification and ring-closing metathesis (Figure 1).

Figure 1. Retrosynthetic analysis of the lactone targets.

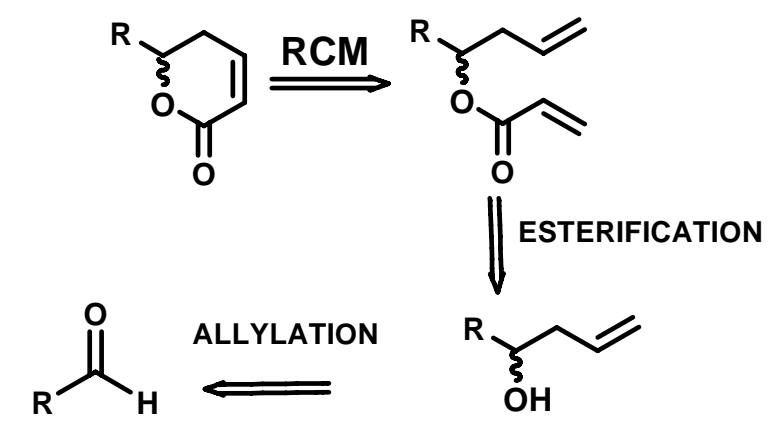

\subsection{Synthesis of the dimer of 6-(4-hydroxy-3-methoxyphenyl)-5,6-dihydro-pyran-2-one (7)}

The synthesis of dilactone 7 is shown in Scheme 1 and discussed below. The hydroxyl group of vanillin was protected with TBSOTf [22], affording the product $\mathbf{2}$ in 99\% yield. Product 2 was allowed to react with allylmagnesium bromide affording in $70 \%$ yield the homoallyl alcohol 3 , which was then treated with acryloyl chloride [23] and DIPEA to produce significant amounts of the corresponding 
acrylate 4. The latter was reactive enough to undergo RCM with the first generation Grubbs ruthenium catalyst [24] $\mathrm{PhCH}=\mathrm{RuCl}_{2}\left(\mathrm{PCy}_{3}\right)_{2}$ with formation of the unsaturated lactone 5 in $60 \%$ yield.

Scheme 1. Synthesis of dimer 7.<smiles>C=CCC(O)c1ccc(OCC)c(OCCNC(=O)c2ccc(OCC)c(OC)c2)c1</smiles>

1

2<smiles>COc1cc(C2CC=CC(=O)O2)ccc1OCCOc1ccc(C2CC=CC(=O)O2)cc1O</smiles>

5

3 c

6

f

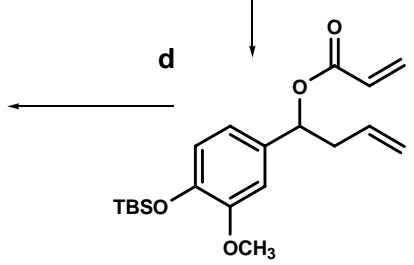

4<smiles>COc1cc(C2CC=CC(=O)O2)ccc1OCCCOc1ccc(C2CC=CC(=O)O2)cc1OC</smiles>

7

Reagents and conditions: a) TBSTf, lutidine, $\mathrm{CH}_{2} \mathrm{Cl}_{2}, 99 \%$; b) allylmagnesium bromide, ether, $0^{\circ} \mathrm{C}, 70 \%$; c) acryloyl chloride, DIPEA, $\mathrm{CH}_{2} \mathrm{Cl}_{2}, 0^{\circ} \mathrm{C}, 97 \%$; d) first generation Grubbs ruthenium catalyst, $\mathrm{CH}_{2} \mathrm{Cl}_{2}, 60^{\circ} \mathrm{C}$, $60 \%$; e) $\mathrm{Bu}_{4} \mathrm{NF}, \mathrm{CH}_{2} \mathrm{Cl}_{2}, 90 \%$; f) 1,3-dibromopropane, $\mathrm{Et}_{3} \mathrm{~N}$, acetonitrile, $69 \%$.

Lactone 5 was allowed to react with tetrabutylammonium fluoride [25] affording lactone 6 in a 90\% yield, which was then treated with 1,3-dibromopropane [26] to finally give a mixture of dilactone 7 $(69 \%)$ and the monosubstitution product.

\subsection{Synthesis of Dilactone 15}

The synthesis of dilactone 15 is shown in Scheme 2 and discussed below. Decanediol 17 was oxidized with PCC, giving product 18 in 65\% yield. Compound 18 was allowed to react with allylmagnesium bromide affording homoallyl alcohol 19 in $43 \%$ yield. Compound 19 was treated with acryloyl chloride, DIPEA to give a $64 \%$ yield of the diester 20, which was submitted to a metathesis reaction with the first generation Grubbs ruthenium catalyst, providing an 80:20 ratio of the dilactone 15 and the dimer in $65 \%$ yield. 
Scheme 2. Synthesis of dilactone 15.<smiles>CC(CO)CO</smiles>

17<smiles>CCNC(=O)C=O</smiles>

18<smiles>C=CCC(O)NC(O)CC=C</smiles>

19<smiles>O=C1C=CCC(NC2CC=CC(=O)O2)O1</smiles><smiles>C=CCC([B]C(CC=C)OC(=O)C=C)OC(=O)C=C</smiles>

20

Reagents and conditions: a) PCC, $\mathrm{CH}_{2} \mathrm{Cl}_{2}, 12 \mathrm{~h}, 65 \% \mathrm{~b}$ ) allylmagnesium bromide, $0^{\circ} \mathrm{C}, 3 \mathrm{~h}, 43 \% \mathrm{c}$ ) Acryloyl chloride, DIPEA, $\mathrm{CH}_{2} \mathrm{Cl}_{2}, 0^{\circ} \mathrm{C}, 64 \%$ d) first generation Grubbs ruthenium catalyst, $\mathrm{CH}_{2} \mathrm{Cl}_{2}, 60^{\circ} \mathrm{C}$, giving dilactone 15 and the corresponding dimer, in $65 \%$ yield (80:20 ratio).

Following similar synthetic strategies, we synthesized the following set of lactones (Figure 2). Lactones 13 and 14 have been synthesized with similar strategies and reported in the literature [27,28]

Figure 2. Others lactones synthesized.<smiles>CC=CC1CC=CC(=O)O1</smiles><smiles>CC=CC1C=CC(=O)O1</smiles>

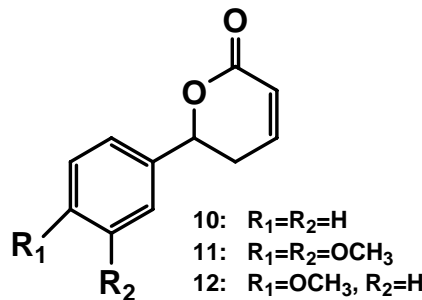<smiles>O=C1CCCC(CCc2ccccc2)O1</smiles>

13<smiles>O=C1C=CCC(/C=C/c2ccccc2)O1</smiles><smiles>O=C1C=CCC(C=CC2CC=CC(=O)O2)O1</smiles>

15
14<smiles>CCCC1CC(OC)CC(=O)O1</smiles>

16

\subsection{Synthesis of compounds $\mathbf{9}, \mathbf{1 5}$ and the Michael adduct $\mathbf{1 6}$}

Lactone 9 was prepared by treating hexadecanal with vinyl magnesium bromide, followed by the esterification and metathesis. In the same way, compound $\mathbf{1 5}$ was prepared following the general methodology previously described, but using decanediol as starting material [29]. Finally, compound 16 was obtained by treatment of lactone 8 with $\mathrm{MeOH}$ and $\mathrm{Et}_{3} \mathrm{~N}$. The synthesis of the remaining 
compounds was achieved in yields ranging $70 \%$ for the allylation (vinylation)-esterification-ring closing metathesis sequence.

\subsection{Leishmanicidal Activity Studies}

The leishmanicidal activity of synthetic compounds as well as glucantime, which was used as control drug, was evaluated following the method reported in the literature $[21,30]$. The results are shown in Table 1 and may provide some insights as to structure-activity relationships.

Table 1. Evaluation of synthetic lactones activity against Leishmania panamensis.

\begin{tabular}{|c|c|c|c|}
\hline \multirow{2}{*}{ Compound } & \multirow{2}{*}{$\begin{array}{l}\text { Cytotoxicity } \\
\text { LC }_{50}(\mu \mathrm{g} / \mathrm{mL})\end{array}$} & \multicolumn{2}{|c|}{ Leishmanicidal Activity } \\
\hline & & $E_{50}(\mu \mathrm{g} / \mathrm{mL})$ & SI* \\
\hline 6 & $27.6 \pm 5.9$ & $37.9 \pm 1.4$ & 0.7 \\
\hline 7 & $54.1 \pm 3.1$ & $22.2 \pm 3.2$ & 2.4 \\
\hline 8 & $3.5 \pm 0.4$ & $0.8 \pm 0.2$ & 4.4 \\
\hline 9 & $33.9 \pm 1.4$ & $2.8 \pm 0.8$ & 12.1 \\
\hline 10 & $1.4 \pm 0.1$ & $4.5 \pm 0.3$ & 0.3 \\
\hline 11 & $0.4 \pm 0.03$ & $1.6 \pm 0.2$ & 0.3 \\
\hline 12 & $1.0 \pm 0.04$ & $8.6 \pm 0.3$ & 0.1 \\
\hline 13 & $2.5 \pm 0.3$ & $7.5 \pm 2.1$ & 0.3 \\
\hline 14 & $2.2 \pm 0.3$ & $1.9 \pm 0.1$ & 1.2 \\
\hline 15 & $1.0 \pm 0.01$ & $1.4 \pm 0.3$ & 0.7 \\
\hline 16 & $51.2 \pm 6.0$ & $47.2 \pm 10.3$ & 1.1 \\
\hline & $3.7^{* *}$ & $0.20^{* *}$ & $18.5^{* *}$ \\
\hline & $4.0^{* *}$ & $0.22^{* *}$ & $18.1^{* *}$ \\
\hline & $45.1^{* *}$ & $3.42^{* *}$ & $13.2^{* *}$ \\
\hline Glucantime & 416.4 & 6.7 & 59.6 \\
\hline
\end{tabular}

$* \mathrm{SI}=\mathrm{LC}_{50} / \mathrm{EC}_{50} ; * *$ biological results reported in the literature [10].

Not only the presence of an $\alpha, \beta$-unsaturated lactone, but also a less polar portion which can be a long aliphatic chain (compound 8) or an aromatic ring (compounds 10,14) appears essential for leishmanicidal activity. The change of the aliphatic side chain (compound 8) for an aromatic ring (compounds 10-14) led to an increase in cytotoxicity and a decrease in activity; however, this ring should not be directly attached to the lactone (6, 13 vs. 14). Additionally, functionalization causes change in biological activity, which is affected by the relative position in the aromatic ring (10 vs $\mathbf{1 1}$ and 12), although cytotoxicity is high still. On the other hand, a large molecule such as dimer 7 is less 
active, even though it has two lactone rings, probably due to steric hindrance of the interaction with a putative receptor, but dimer 15, which also has two lactone rings, displays a significant activity, even though it is smaller than compound 7. However, dimer $\mathbf{1 5}$ has a similar activity to compound $\mathbf{8}$, but improved cytotoxicity. Perhaps, the improved activity of $\mathbf{1 5}$ is related to the lipophilic central chain joining the lactone rings. However, the central chain cannot be as large as in the case of dimeric molecule 7, otherwise activity will be compromised.

Regarding changes in the lactone ring, the reduction of the ring size (compound 9) leads to a considerable decrease in cytotoxicity ( 3.5 vs $33.9,8$ vs $\mathbf{9}$ ), but its activity is three times lower ( 2.8 vs 0.8 compound 8). However, surprisingly, the $\gamma$-lactone shows a high level of leishmanicidal activity and its cytotoxicity is lower than for the $\delta$-lactone. In Michael adduct $\mathbf{1 6}$ both cytotoxicity and activity decrease significantly, which confirms the importance of the $\alpha, \beta$-unsaturated carbonyl system in this type of compounds.

In general, most of the compounds have significant activity in L. panamensis amastigotes, exhibiting an $\mathrm{EC}_{50}$ of less than $10.0 \mathrm{mg} / \mathrm{mL}$ (Table 1). With regard to selectivity index (SI = $\left.\mathrm{LC}_{50} / \mathrm{EC}_{50}\right)$ compound $9(\mathrm{SI}=12.1)$ would be the most promising, because of its simple structure and low $\mathrm{LC}_{50}$ (33.9). These results are comparable with the previously reported leishmanicidal activity of lactams [7].

\section{Experimental}

\subsection{General}

NMR spectra were recorded as $\mathrm{CDCl}_{3}$ solutions on a Bruker AMX 300 instrument operating at 300 $\mathrm{MHz}$ for ${ }^{1} \mathrm{H}$ and $75 \mathrm{MHz}$ for ${ }^{13} \mathrm{C}$. Chemical shifts $(\delta)$ are expressed in ppm with the solvent peak as reference; coupling constants $(J)$ are given in Hertz $(\mathrm{Hz})$. Multiplicity assignments of ${ }^{13} \mathrm{C}$ signals were made by means of the DEPT pulse sequence. High resolution mass spectra were run in the electron impact mode (EIMS $70 \mathrm{eV}$ ). IR data were measured with oily films on $\mathrm{KBr}$ pellets (solids) on a Perkin-Elmer RXI-2000 (FT-IR). Experiments which required an inert atmosphere were carried out under dry $\mathrm{N}_{2}$ in flame-dried glassware. $\mathrm{Et}_{2} \mathrm{O}$ and $\mathrm{THF}$ were freshly distilled from sodium/benzophenone and transferred via syringe. Dichloromethane was freshly distilled from $\mathrm{CaH}_{2}$. Commercially available reagents were used as received. Unless otherwise indicated, "work-up" means pouring the reaction mixture into brine, followed by extraction with the solvent indicated in parenthesis. If the reaction medium was acidic (basic), an additional wash with $5 \%$ aq $\mathrm{NaHCO}_{3}$ (aq $\mathrm{NH}_{4} \mathrm{Cl}$ ) was performed. Washing with brine, drying over anhydrous $\mathrm{Na}_{2} \mathrm{SO}_{4}$ and elimination of the solvent under reduced pressure were followed by chromatography on a silica gel column $(60-200 \mu \mathrm{m})$ with the indicated eluent.

\subsection{General synthetic procedures}

4-(tert-Butyldimethylsilanyloxy)-3-methoxybenzaldehyde (2): Vanillin (1, $1 \mathrm{~g}, 6.57 \mathrm{mmol}$ ) was dissolved under $\mathrm{N}_{2}$ in dry $\mathrm{CH}_{2} \mathrm{Cl}_{2}(20 \mathrm{~mL})$ and treated sequentially with 2,6-lutidine $(1.14 \mathrm{~mL}, 9.86$ mmol) and TBSOTf $(1.66 \mathrm{~mL}, 7.23 \mathrm{mmol})$. The reaction mixture was then stirred for $1 \mathrm{~h}$ at $0^{\circ} \mathrm{C}$. After this time the reaction mixture was poured onto a saturated aq. $\mathrm{NH}_{4} \mathrm{Cl}$ solution and extracted with 
$\mathrm{CH}_{2} \mathrm{Cl}_{2}$. Column chromatography on silica gel (hexanes-EtOAc 4:1) afforded the desired silylated derivative 2 in 99\% yield. ${ }^{1} \mathrm{H}-\mathrm{NMR}: \delta 0.00(\mathrm{~s}, 6 \mathrm{H}), 0.85(\mathrm{~s}, 9 \mathrm{H}), 3.62(\mathrm{~s}, 3 \mathrm{H}), 6.61(\mathrm{dd}, 2 \mathrm{H}, J=9.3$ $\mathrm{Hz}, J=8 \mathrm{~Hz}), 6.70(\mathrm{~s}, 1 \mathrm{H}), 9.80(\mathrm{~s}, 1 \mathrm{H}) ;{ }^{13} \mathrm{C}-\mathrm{NMR}: \delta 18.30(\mathrm{C}), 25.50\left(\mathrm{CH}_{3}\right), 46.80\left(\mathrm{CH}_{3}\right), 73.60$ $(\mathrm{CH}), 110.20(\mathrm{CH}), 118.10(\mathrm{CH}), 120.20(\mathrm{CH}), 137.30(\mathrm{C}), 143.60(\mathrm{C}), 150.30(\mathrm{C}), 189.00(\mathrm{CH})$.

1-[4-(tert-Butyldimethylsilanyloxy)-3-methoxyphenyl]-but-3-en-1-ol (3): The aldehyde 2 (0.18 mmol) was dissolved in dry ether $(50 \mathrm{~mL})$ a $0^{\circ} \mathrm{C}$, allylmagnesium bromide $(0.18 \mathrm{mmol}, 1 \mathrm{M}$ solution in $\mathrm{THF})$ was added and then the mixture was stirred for $4 \mathrm{~h}$ under $\mathrm{N}_{2}$. The reaction mixture was then quenched through addition of a saturated aq. solution of $\mathrm{NH}_{4} \mathrm{Cl}$ and extracted with $\mathrm{Et}_{2} \mathrm{O}$. The combined organic phases were washed with a saturated aq. solution of $\mathrm{NaCl}$, and dried with $\mathrm{Na}_{2} \mathrm{SO}_{4}$. After filtration and evaporation of the solvent under vacuum the residue was column chromatography on silica gel (hexanes-EtOAc 8:2 and then 3:2) to afford the homoallylic alcohol in 70\% yield. ${ }^{1} \mathrm{H}-\mathrm{NMR}: \delta 0.00$ (s, $6 \mathrm{H}), 0.85(\mathrm{~s}, 9 \mathrm{H}), 2.29(\mathrm{t}, 2 \mathrm{H}, J=6.8 \mathrm{~Hz}), 3.62(\mathrm{~s}, 3 \mathrm{H}), 4.43(\mathrm{t}, 1 \mathrm{H}, J=6.5 \mathrm{~Hz}), 4.90-4.96(\mathrm{~m}, 1 \mathrm{H})$, 5.57-5.63 (m, 2H), $6.61(\mathrm{dd}, 2 \mathrm{H}, J=9.3 \mathrm{~Hz}, J=8 \mathrm{~Hz}), 6.70(\mathrm{~s}, 1 \mathrm{H}) ;{ }^{13} \mathrm{C}-\mathrm{NMR}: \delta 18.32,25.52\left(\mathrm{CH}_{3}\right)$, $43.84\left(\mathrm{CH}_{2}\right), 46.86\left(\mathrm{CH}_{3}\right), 73.65(\mathrm{CH}), 110.20(\mathrm{CH}), 117.70\left(\mathrm{CH}_{2}\right), 118.11(\mathrm{CH}), 120.22(\mathrm{CH}), 134.83$ $(\mathrm{CH}), 137.34(\mathrm{C}), 150.38(\mathrm{C}), 143.66(\mathrm{C})$.

Acrylic acid 1-[4-(tert-butyldimethylsilanyloxy)-3-methoxyphenyl]-but-3-enyl ester (4): Alcohol 3 $(0.75 \mathrm{mmol})$ was dissolved under $\mathrm{N}_{2}$ in dry $\mathrm{CH}_{2} \mathrm{Cl}_{2}(11 \mathrm{~mL})$, cooled to $0^{\circ} \mathrm{C}$, and treated sequentially with DIPEA (3.74 mmol) and acryloyl chloride $(32.26 \mathrm{mmol})$. The reaction mixture was stirred for $2 \mathrm{~h}$ at $0^{\circ} \mathrm{C}$ and then work-up (extraction with $\mathrm{CH}_{2} \mathrm{Cl}_{2}$ ). Column chromatography on silica gel (hexanesEtOAc 4:2) afforded ester 4 in 97\% yield. ${ }^{1} \mathrm{H}-\mathrm{NMR}: \delta 0.14(\mathrm{~s}, 6 \mathrm{H}), 0.99(\mathrm{~s}, 9 \mathrm{H}), 2.50-2.70(\mathrm{~m}, 2 \mathrm{H})$, $3.80(\mathrm{~s}, 3 \mathrm{H}), 5.01-5.11(\mathrm{~m}, 3 \mathrm{H}), 5.79-5.85(\mathrm{~m}, 2 \mathrm{H}), 6.10-6.20(\mathrm{~m}, 1 \mathrm{H}), 6.41(\mathrm{dd}, 1 \mathrm{H}, J=1.0 \mathrm{~Hz}, J=$ $17.3 \mathrm{~Hz}), 6.70-6.80(\mathrm{~m}, 2 \mathrm{H}), 6.80(\mathrm{~s} \mathrm{br}, 1 \mathrm{H}) ;{ }^{13} \mathrm{C}-\mathrm{NMR}$ : $\delta 18.30(\mathrm{C}), 26.49\left(\mathrm{CH}_{3}\right), 40.39\left(\mathrm{CH}_{2}\right), 55.48$ $\left(\mathrm{CH}_{3}\right), 75.19(\mathrm{CH}), 110.71(\mathrm{CH}), 117.99(\mathrm{CH}), 119.00\left(\mathrm{CH}_{2}\right), 120.50(\mathrm{CH}), 128.60(\mathrm{CH}), 130.80$ $\left(\mathrm{CH}_{2}\right), 133.30(\mathrm{CH}), 134.50(\mathrm{C}), 144.70(\mathrm{C}), 150.70(\mathrm{C}), 165.34(\mathrm{C})$.

6-[4-(tert-Butyldimethylsilanyloxy)-3-methoxyphenyl]-5,6-dihydropyran-2-one (5): Compound 4 (0.86 mmol) was dissolved under $\mathrm{N}_{2}$ in dry, degassed $\mathrm{CH}_{2} \mathrm{Cl}_{2}(35 \mathrm{~mL})$ and treated with ruthenium catalyst $\mathrm{PhCH}=\mathrm{RuCl}_{2}\left(\mathrm{PCy}_{3}\right)_{2}(10 \% \mathrm{mmol})$. The mixture was heated at reflux until consumption of the starting material (ca. $3 \mathrm{~h}$, TLC monitoring!). Solvent removal in vacuum and column chromatography on silica gel (hexanes-EtOAc, 9:1) furnished lactone 5 in 60\% yield. ${ }^{1} \mathrm{H}-\mathrm{NMR}: \delta 0.00(\mathrm{~s}, 6 \mathrm{H}), 0.84(\mathrm{~s} \mathrm{br}, 9 \mathrm{H})$, 2.37-2.57 (m, 2H), 3.67 (s, 3H), $5.22(\mathrm{dd}, 1 \mathrm{H}, J=4.3 \mathrm{~Hz}, J=7.4 \mathrm{~Hz}), 5.96$ (d, $1 \mathrm{H}, J=9.8 \mathrm{~Hz}), 6.63-6.70$ (m, 2H), 6.78- $6.83(\mathrm{~m}, 2 \mathrm{H}) ;{ }^{13} \mathrm{C}-\mathrm{NMR}: \delta 18.18,25.29\left(\mathrm{CH}_{3}\right), 31.60\left(\mathrm{CH}_{2}\right), 55.45\left(\mathrm{CH}_{3}\right), 79.32(\mathrm{CH})$, 109.94(CH), 118.60(CH), 120.64(CH), 121.48(CH), $131.85(\mathrm{C}), 144.89(\mathrm{CH}), 145.31(\mathrm{C}), 151.13(\mathrm{C})$, $164.44(\mathrm{C})$.

6-(4-Hydroxy-3-methoxyphenyl)-5,6-dihydropyran-2-one (6): The silylated lactone 5 (0.1 g, $0.3 \mathrm{mmol})$ was dissolved in THF $(10 \mathrm{~mL})$, treated with TBAF $(5 \mathrm{mg}, 0.0007 \mathrm{mmol})$ and the mixture stirred for 9 $\mathrm{h}$ at $25^{\circ} \mathrm{C}$. The reaction was then quenched by addition of a solution of $\mathrm{NH}_{4} \mathrm{Cl}$, and after work-up $\left(\mathrm{CH}_{2} \mathrm{Cl}_{2}\right)$, the organic phase was washed with a saturated $\mathrm{NaCl}$ solution, dried with $\mathrm{Na}_{2} \mathrm{SO}_{4}$, and evaporated under vacuum. The residue was subjected to column chromatography on silica gel (hexanes-EtOAc 1:1 and 3:2) furnishing lactone 6 as an amorphous solid in 89.3\% yield. Mp: 109-111 
${ }^{\circ} \mathrm{C}$; IR (KBr) v $v_{\max }\left(\mathrm{cm}^{-1}\right): 3392(\mathrm{OH}), 1709(\mathrm{C}=\mathrm{O}), 1136(\mathrm{C}(=\mathrm{O})-\mathrm{O}), 1033\left(\mathrm{O}-\mathrm{C}=\mathrm{C}, \mathrm{O}-\mathrm{CH}_{3}\right) ;{ }^{1} \mathrm{H}-$ NMR: $\delta$ 2.51- $2.69(\mathrm{~m}, 2 \mathrm{H}), 3.91(\mathrm{~s}, 3 \mathrm{H}), 5.38(\mathrm{dd}, 1 \mathrm{H}, J=4.5 \mathrm{~Hz}, J=11.5 \mathrm{~Hz}), 5.72(\mathrm{~s} \mathrm{br}, 1 \mathrm{H}), 6.13(\mathrm{dd}$, $1 \mathrm{H}, J=2.2 \mathrm{~Hz}, J=9.8 \mathrm{~Hz}), 6.85-6.90(\mathrm{~m}, 2 \mathrm{H}), 6.90-7.00(\mathrm{~m}, 2 \mathrm{H}) ;{ }^{13} \mathrm{C}-\mathrm{NMR}: \delta 32.02\left(\mathrm{CH}_{2}\right), 56.16\left(\mathrm{CH}_{3}\right)$, 79.62(CH), 109.03(CH), 114.50(CH), 119.50(CH), 121.93(CH), 130.88, 145.21(CH), 146.69, 147.48; HR EIMS, m/z $221.1902(\mathrm{M}+\mathrm{H})$.

Dimer of 6-(4-hydroxy-3-methoxyphenyl)-5,6-dihydropyran-2-one (7): Lactone 6 was dissolved in acetonitrile $(10 \mathrm{~mL}), \mathrm{Et}_{3} \mathrm{~N}(1.5 \mathrm{eq}, 2.3 \mathrm{~mL})$ was added and the reaction mixture stirred for $15 \mathrm{~min}$. Then 1,3-dibromopropane ( $0.5 \mathrm{eq}, 0.02 \mathrm{~mL}$ ) was added, and the resulting mixture was heated at reflux for $8 \mathrm{~h}$. After this time an aq. solution of $\mathrm{HCl}$ was added and the mixture was extracted with EtOAc. The combined organic phases were dried over $\mathrm{Na}_{2} \mathrm{SO}_{4}$, filtered and concentrated under vacuum. The residue was subjected to column chromatography on silica gel (hexanes-EtOAc 9:1) to furnish dimeric compound 7 in $69 \%$ yield. Mp: 81-83 ${ }^{\circ} \mathrm{C}$; I.R $(\mathrm{KBr}) v_{\max }\left(\mathrm{cm}^{-1}\right): 1708(\mathrm{C}=\mathrm{O}), 1171(\mathrm{C}(=\mathrm{O})-\mathrm{O}), 1128$ $\left(\mathrm{O}-\mathrm{C}=\mathrm{C}, \mathrm{O}-\mathrm{CH}_{3}\right)$; ${ }^{1} \mathrm{H}-\mathrm{NMR}: \delta 2.21-2.26(\mathrm{~m}, 2 \mathrm{H}), 2.32-2.41(\mathrm{~m}, 2 \mathrm{H}), 3.89(\mathrm{~s}, 3 \mathrm{H}), 4.15-4.32(\mathrm{~m}$, $4 \mathrm{H}), 5.28-5.44(\mathrm{~m}, 2 \mathrm{H}), 5.65-5.97(\mathrm{~m}, 2 \mathrm{H}), 6.78-7.01(\mathrm{~m}, 8 \mathrm{H}) ;{ }^{13} \mathrm{C}-\mathrm{NMR}: \delta 29.69\left(\mathrm{CH}_{2}\right), 56.061\left(\mathrm{CH}_{3}\right)$, $61.89\left(\mathrm{CH}_{2}\right), 109.82(\mathrm{CH}), 123.659(\mathrm{CH}), 133.220,145.97(\mathrm{CH})$; HR EIMS, $(\mathrm{M}+\mathrm{H}): 481.2$

Dilactone 6,6'-octane-1,8-diylbis(5,6-dihydro-2H-pyran-2-one) (15): Amorphous solid. Mp: 81-84 ${ }^{\circ} \mathrm{C}$; IR $(\mathrm{KBr}) v_{\max }\left(\mathrm{cm}^{-1}\right): 1698(\mathrm{C}=\mathrm{O}), 1262(\mathrm{C}(=\mathrm{O})-\mathrm{O}), 1028(\mathrm{O}-\mathrm{C}=\mathrm{C}) ;{ }^{1} \mathrm{H}-\mathrm{NMR}: \delta$ 1.25-1.37 (m, $14 \mathrm{H}), 1.56-1.67(\mathrm{~m}, 4 \mathrm{H}), 2.30-2.35(\mathrm{~m}, 4 \mathrm{H}), 4.37-4.46(\mathrm{~m}, 2 \mathrm{H}), 6.02\left(\mathrm{~d}, J=9.8 \mathrm{~Hz}, 2 \mathrm{H}_{2}\right), 6.87(\mathrm{~m}$, $\left.2 \mathrm{H}_{3}\right) ;{ }^{13} \mathrm{C}-\mathrm{NMR}: \delta\left(\mathrm{CH}_{2}\right), 29.90-30.10\left(6 \mathrm{CH}_{2}\right), 35.50\left(\mathrm{CH}_{2}\right), 78.20(\mathrm{CH}), 122.10(\mathrm{CH}), 145.80(\mathrm{CH})$, 165.20; HR EIMS: $(\mathrm{M}+\mathrm{H}): 307.1911\left(\mathrm{C}_{18} \mathrm{H}_{27} \mathrm{O}_{4}\right)$, calc. 307.1909.

6-Dodecyl-4-methoxytetrahydro-pyran-2-one (16): The lactone 8 (200 mg, $0.962 \mathrm{mmol})$ was dissolved in $\mathrm{MeOH}(30 \mathrm{~mL})$, and treated with $\mathrm{Et}_{3} \mathrm{~N}(0.962 \mathrm{mmol})$. The mixture was heated at reflux until the starting material was consumed (ca. $4 \mathrm{~h}$, TLC monitoring); after this time, the mixture is neutralized with a solution of sodium bicarbonate, extracted with ethyl acetate, and the organic phase dried with $\mathrm{Na}_{2} \mathrm{SO}_{4}$, concentrated and purified by column chromatography (silica gel, hexane: ethyl acetate 1:1 ) to give an amorphous solid. Mp: $54-56{ }^{\circ} \mathrm{C}$; IR $(\mathrm{KBr}) v_{\max }\left(\mathrm{cm}^{-1}\right): 1724(\mathrm{C}=\mathrm{O}), 1245(\mathrm{C}(=\mathrm{O})-\mathrm{O}), 1081$ $\left(\mathrm{O}-\mathrm{C}=\mathrm{C}, \mathrm{O}-\mathrm{CH}_{3}\right) ;{ }^{1} \mathrm{H}-\mathrm{NMR}: \delta 0.88(\mathrm{t}, 3 \mathrm{H}, \mathrm{J}=6.6 \mathrm{~Hz}), 1.25-1.38(\mathrm{~m}, 26 \mathrm{H}), 1.60-1.70(\mathrm{~m}, 2 \mathrm{H}), 2.03-$ $2.17(\mathrm{~m}, 2 \mathrm{H}), 2.67-2.69(\mathrm{~m}, 2 \mathrm{H}), 3.33(\mathrm{~s}, 3 \mathrm{H}), 3.70-3.80(\mathrm{~m}, 1 \mathrm{H}), 4.49-4.58(\mathrm{~m}, 1 \mathrm{H}) ;{ }^{13} \mathrm{C}-\mathrm{NMR}: \delta$ $14.11\left(\mathrm{CH}_{3}\right), 22.68$ - $29.69\left(10 \mathrm{CH}_{2}\right), 31.92\left(\mathrm{CH}_{2}\right), 33.17\left(\mathrm{CH}_{2}\right), 35.52\left(\mathrm{CH}_{2}\right), 56.09\left(\mathrm{CH}_{3}\right), 71.47(\mathrm{CH})$, $75.91(\mathrm{CH})$; HR EIMS, $(\mathrm{M}+\mathrm{H}): 341.3044 \mathrm{C}_{21} \mathrm{H}_{41} \mathrm{O}_{3}$ calc.341.3056.

\subsection{Bioassays}

Leishmanicidal activity and cytotoxicity were measured according to previously reported procedures [21].

\section{Conclusions}

A number of aliphatic and aromatic lactones as well as two dimers were synthesized and evaluated against amastigotes of Leishmania panamensis. The analysis of the results showed that the lactones 
with an aliphatic side chain are more active and less cytotoxic than lactones with aromatic side chains. We also found that reducing the size of the lactone ring results in increased activity and selectivity index. Furthermore, it confirms the importance of the $\alpha, \beta$-unsaturated lactone moiety for biological activity in this area.

\section{Acknowledgements}

The authors thank COLCIENCIAS and the University of Antioquia for financial support.

\section{References and Notes}

1. Ouellette, M. Biochemical and molecular mechanisms of drug resistance in parasites. Trop. Med. Int. Health 2001, 6, 874-882.

2. www.who.int/tdr/diseases/default.htm.

3. www.who.int/infectious-disease-report/2009/ch4.htm.

4. Hoffmann, H.M.R.; Rabe, J. Synthesis and Biological Activity of $\alpha$-Methylene- $\gamma$-butyrolactones. Angew. Chem. Int. Ed. Engl. 1985, 24, 94-110.

5. Negishi, E.; Kotora. M. Regio- and stereoselective synthesis of gamma-alkylidene butenolides and related compounds. Tetrahedron 1997, 53, 6707-6738.

6. Collins, I. Saturated and unsaturated lactones. J. Chem. Soc. Perkin Trans. I 1999, 1377-1396.

7. Carter, N.B.; Nadany, A.E.; Sweeney, J.B. Recent developments in the synthesis of furan-2(5H)ones. J. Chem. Soc. Perkin Trans. I 2002, 34, 2324-2342.

8. Saeed, M.; Thomas, H.; Schick, M.; Abbas, M.; Voelter, W. Total synthesis and antileishmanial activity of R-(-)-argentilactone. Tetrahedron Lett. 2001, 42, 7401-7403.

9. Davies-Coleman, M.; Rivett, D. Stereochemical studies on boronolide, an $\alpha$-pyrone from Tetradenia barberae. Phytochemistry 1987, 26, 3047-3050.

10. Cardona, W.; Quinones W.; Robledo, S.; Velez, I.; Murga, J.; Garcia-Fortanet, J.; Carda, M.; Cardona, D.; Echeverri, F. Antiparasite and antimycobacterial activity of passifloricin analogues. Tetrahedron 2006, 62, 4086-4092.

11. Kirkland, T.A.; Grubbs, R.H. Effects of Olefin Substitution on the Ring-Closing Metathesis of Dienes. J. Org. Chem. 1997, 62, 7310-7318.

12. Bassetti, M.; D’Annibale, A. Synthesis of $\alpha, \beta$-Unsaturated 4,5-Disubstituted $\gamma$-Lactones via RingClosing Metathesis Catalyzed by the First-Generation Grubbs' Catalyst. Org. Lett. 2005, 7, 1805-1808.

13. Schuster, M.; Blechert, S.A. An Olefin Metathesis/Double Bond Isomerization Sequence Catalyzed by an In Situ Generated Ruthenium Hydride Species. Angew. Chem. Int. Ed. 1997, 36, 2036-2055.

14. Grubbs, R.H.; Chang, S. Recent Advances in Olefin Metathesis and Its Application in Organic Synthesis. Tetrahedron 1998, 54, 4413-4450.

15. Fürstner, A.; Grela, K. Ring Closing Alkyne Metathesis. Application to the Stereoselective Total Synthesis of Prostaglandin E2-1,15 Lactone. Angew. Chem. Int. Ed. 2000, 39, 1234-1236.

16. Armstrong, S.K. Ring closing diene metathesis in organic synthesis. J. Chem. Soc. Perkin Trans. 1998, 1, 371-388.

17. Gosh, A.K.; Liu, C.A. Stereoselective Synthesis of (-)-Tetrahydrolipstatin. Chem. Commun. 1999, 1743-1744. 
18. Cossy, J.; Bauer, D.; Bellosta, V. Oxidation of Substituted Spiro[bicyclo[n.1.0]alkane-2,2'[1,3]dioxolanes]. Formation of substituted lactones. Tetrahedron Lett. 1999, 40, 4187-4188.

19. Ramachandran, P.V.; Reddy, M.V.R.; Brown, H.C. Asymmetric synthesis of goniothalamin, hexadecanolide, massoia lactone, and parasorbic acid via sequential allylboration-esterification ring-closing metathesis reactions. Tetrahedron Lett. 2000, 41, 583-586.

20. Carda, M.; Rodriguez, S.; Gonzalez, F.; Castillo, E.; Villanueva, A.; Marco,J. A. Stereoselective Synthesis of the Naturally Occurring Lactones (-)-Osmundalactone and (-)-Muricatacine Using Ring-Closing Metathesis. Eur. J. Org. Chem. 2002, 15, 2649-2655.

21. Cardona, W.; Quinones, W.; Echeverri, F. Leishmanicidal Activity of Passifloricin A and Derivatives. Molecules 2004, 9, 666-672.

22. Corey, E.J.; Cho, H.; Rucker, C.; Hua, D. Studies with trialkylsilyltriflates: new syntheses and applications. Tetrahedron Lett. 1981, 22, 3455-3458.

23. Cossy, J.; Bauer, D.; Bellosta, V. Formal total synthesis of (+)-methynolide. Tetrahedron 2002, 58, 5909-5922.

24. Trnka, T.; Grubbs, R. The Development of $\mathrm{L}_{2} \mathrm{X}_{2} \mathrm{Ru}=\mathrm{CHR}$ Olefin Metathesis Catalysts: An Organometallic Success Story: Grubbs. Acc. Chem. Res. 2001, 34, 18-29.

25. Clark, S.; Whitlock,G. A Short Synthesis of ( \pm )-Decarestrictine L. Tetrahedron Lett. 1994, 35, 6381-6382.

26. Mayence, A.; Pietka, A.; Collins, M.S.; Cushion, M.T.; Tekwani, B.L.; Huang, T.L.; Vanden Eynde, J.J. Novel bisbenzimidazoles with antileishmanial effectiveness. Bioorg. Med. Chem. Lett. 2008, 18, 2658-2661.

27. Nakashima, K.; Imoto, M.; Miki, T.; Miyake, T.; Fujisaki, N.; Fukunaga, S.; Mizutani, R.; Sono, M.; Tori, M. Ring closing metathesis reaction of dienes with acrylate moiety leading to 5- to 7membered lactones and cyclization to 14-membered rings. Heterocycles 2002, 56, 85-89.

28. Pilli, R.; Fatima, N. Synthetic process for the preparation of (R)-(+)- and (S)-(-)-goniothalamin and derivatives via asymmetric catalytic allylation of aldehydes, esterification, and olefin metathesis reaction. BR 2003003756 A 20050419, 2005.

29. Murga, J.; Garcia-Fortanet, J.; Carda, M.; Marco, J.A. Asymmetric synthesis of passifloricin A: a correction in structure. Tetrahedron Lett. 2003, 44, 7909-7912.

30. Sereno, D.; Lemestre, L. Use of an enzymatic micromethod to quantify amastigote stage of Leishmania amazonensis in vitro. Parasitol. Res. 1997, 83, 401-403.

Sample Availability: Samples of the compounds 8-16 and NMR and MS spectra are available from the authors.

(C)2009 by the authors; licensee Molecular Diversity Preservation International, Basel, Switzerland. This article is an open-access article distributed under the terms and conditions of the Creative Commons Attribution license (http://creativecommons.org/licenses/by/3.0/). 